\title{
Psychoparatekstualność życia codziennego
}

\section{Kenneth Goldsmith}

Przeglądałem właśnie Parateksty Genette’a w PDF-ie, gdy zdarzyła się zabawna rzecz. Przewijałem kolejne „strony”, kiedy nagle, około strony 160, PDF przestał wyświetlać zawartość. Następne trzysta stron było puste. Trudno sobie wyobrazić, by to samo zdarzyło się Genette'owi w czasach, gdy pisał swą książkę. Jeśli elektroniczne glitche pustoszyły tekst, wiedziała o tym zaledwie garstka geeków ${ }^{1}$; PDF-y wtedy nawet nie istniały. Obecność tekstu była czymś, co Genette przyjmował za pewnik: otwieramy książkę i tekst w niej jest. Ta stabilność umożliwiła teorię paratekstów. Lecz co się dzieje, gdy tekst znika? Choć parateksty mogą istnieć bez tekstu, książka bez tekstu wykraczała poza horyzont Genette'a. Ale mogę się mylić - być może omawiał to na ostatnich trzystu stronach swojej książki. Nigdy się nie dowiem. W pewnym sensie pokaźna część tekstu Genette’a nabrała zatem w moim doświadczeniu paratekstualnego charakteru. Owa sytuacja okazuje się niezamierzonym proroctwem, jako że w XXI wieku tekst i jego konsumpcja to ostatnie rzeczy, jakimi się przejmujemy. Jest inaczej: samo pojęcie tekstualności stało się paratekstualne.

Kwestia ilości. Być może Genette nie mógł sobie wyobrazić, że będziemy posiadać tak potężną (na miarę epoki cyfrowej) ilość tekstów, których nigdy nie przeczytamy. Choć jego horyzont naukowy był rozległy, był też, co zrozumiałe, ograniczony, a w jego zasięgu mieściło się tylko to, co mogły pomieścić regały na książki. Dziś jesteśmy przytłoczeni ogromną ilością tekstów, których nigdy nie przeczytamy, co sprawia, że samo czytanie staje się paratekstualne wobec faktyczności artefaktu. Dysk twardy mam zabałaganiony pierdyliardami nieprzeczytanych PDF-ów i EPUBów; ściągnąłem je, ponieważ usługi wymiany plików pozwoliły mi to zrobić za darmo. Nie mogę uwierzyć, że rzeczy, za które dekadę lub dwie temu słono bym zapłacił, kosztują tylko tyle, co kliknięcie. Czy to najlepsze kopie? Nie. Tak jak mój PDF z Genette’em mają błędy, ale biorę je,

\footnotetext{
${ }^{1}$ Chcieliśmy zachować idiom tekstu, który oscyluje pomiędzy naukową precyzją a językiem potocznym i komputerowym slangiem. Dlatego też czytelnik znajdzie w tekście używane w języku polskim przez informatyków zapożyczenie glitche (a nie „usterki”, „błędy oprogramowania”) albo „geeków” (a nie „informatycznych zapaleńców”) [przyp. tłum.].
} 
bo są za darmo. Glitch jest częścią ekosystemu wolnej kultury, wskazuje na użycie i odzwierciedla historię. Ślady technologii są śladami pierwiastka ludzkiego, paratekstualnymi elementami dodanymi do artefaktów kulturowych. Może nie jestem w stanie przeczytać mojego PDF-a, ale mogę być posiadaczem jego kopii - nawet i niedoskonałej - co sprawia, że czytanie (tekstualność) staje się paratekstualne wobec doświadczenia ściągnięcia pliku.

Słucham właśnie utworu Django Reinhardta pod tytułem Improvisation zrzuconego z longplaya Swing From Paris. Wyszukiwanie prowadzi mnie do paratekstualnej informacji dyskograficznej, że plik, którym dysponuję, jest zrzutem z małej dziesięciocalowej płyty wydanej przez London Records w 1954 roku, którą jakaś życzliwa dusza skonwertowała do formatu MP3 i podzieliła się plikiem. Nagranie przesycone jest glitchami - szmerami, przeskokami i trzaskami. Choć nie zaprzepaszczają muzyki w taki sam sposób, w jaki PDF z Genette'em zaprzepaścił tekst, usuwają jej część (przeskok literalnie przeskakuje fragment utworu), a szmery i trzaski tworzą akustyczną warstwę pod całym nagraniem; to artefakty, których obecności Reinhardt nie zakładał. Dziesięciocalowemu longplayowi, w jego oryginalnym formacie towarzyszyła mnogość materiałów paratekstualnych - naklejka wytwórni, okładka, książeczka itd. - ale wszystkie zniknęły, gdy ściągnąłem go jako MP3. Improvisation jest zatem dryfującym artefaktem, czymś co nazywam „nagim medium”, pozbawionym pochodzenia, wyrwanym z pierwotnego kontekstu, to znaczy, pozbawionym paratekstów. W taki sposób większość kulturowych artefaktów trafia dzisiaj na nasze dyski. Lecz wobec braków tradycyjnej paratekstualności, wyłaniają się nowe parateksty, związane ze sprzętem - sieci, serwery, platformy dystrybucji, oprogramowanie.

Gdy artefakt trafia na mój pulpit, nosi w sobie historię kogoś innego. Każde zadrapanie i przeskok wskazuje na rozlany kieliszek wina albo paznokieć przebiegający w poprzek rowków podczas niezdarnej próby zamocowania płyty na trzpieniu. Mogę podjąć się psychogeograficznej rekonstrukcji historii owego MP3 - tego, w jaki sposób zostało zadrapane - ale to wszystko mrzonka. Tak naprawdę nie mam pojęcia. Moja romantyczna rekonstrukcja i królicze nory pamięci, w które w rezultacie wpadam, to psychoparateksty. Z czasem, tak samo jak psychogeografia, owe psychoparatekstualne elementy stopiły się z moim życiem. Z czasem zadrapania na mojej kopii Improvisation stały się moimi zadrapaniami. Wraz z tym, jak kawałek Django mości się w moim życiu - jako ścieżka dźwiękowa podczas długich podróży autobusem albo w tle rozmowy podczas wieczornego przyjęcia - owe przeskoki i zadrapania stają się moimi przeskokami i zadrapaniami, jakby powstały w okolicznościach mojego życia. Owe parateksty są teraz jego pierwszoplanową ścieżką dźwiękową. Jako że przy raz pobranym MP3 nie da się już majstrować - pewnie nie podejmę nawet prób czyszczenia go - owe skazy stały się trwałymi cechami.

Chodźmy krok dalej: owe zadrapania są psychoparatekstualnymi portalami do mojej historii, dźwiękami mojej młodości. Gdy byłem młody, dźwięk nigdy nie był „czysty”; kasety magnetofonowe topiły się w upalne letnie dni na samochodowych deskach rozdzielczych, wypaczając Led Zeppelin IV w polifonie rodem ze Stockhausena. Radio nadające Ronettes na długich falach i na cały regulator uporczywie wypełnione było szumem; gdy wjeżdżałem do tunelu na autostradzie, gubiłem dźwięk kompletnie, tak jak straciłem fragment PDF-a z Genette’em. Kładłem płyty Beatlesów jedna na drugiej na trzpieniu gramofonu, przez co, spadając na siebie, nawzajem się niszczyły; tak jak Mémoires Deborda i Jorna niszczyły książki stojące obok 
na półce 2 . Gdy Revolver kładłem na Sgt. Pepper’s, spotkanie dwóch powierzchni przyniosło wzajemną destrukcję; prawie jak w sado-maso, każda z radością nosiła blizny przeżytego za obopólną zgodą zbliżenia. Gdybym chciał zrobić własny plik MP3 z owych nagrań, ich indywidualny zbiór zadrapań, byłby znakiem ich wyjątkowości. Oficjalne wersje Revolver sprzedawane jako MP3 są identycznie czystymi kopiami, którym brakuje tego bogactwa paratekstualnych ekosystemów. Dłoń każdego użytkownika dzielącego się plikami, powielając ich skazy, ponownie wpisuje paratekstualność w artefakt.

Skoro tak, to czy możemy powiedzieć, że nostalgia stanowi paratekst dla każdego doświadczenia? Jadę przez Long Island, przeskakuję stacje radiowe i nagle, ni z tego, ni z owego, leci Wendy Beach Boys. Zostaję natychmiast wyrwany z tekstu roku 2016 i wrzucony w moją paratekstualność lata 1976 roku. Wciąż prowadzę samochód w roku 2016, ale staje się to paratekstualne/peryferyjne wobec fali nostalgii wywołanej przez piosenkę, która teraz jest na pierwszym planie. Myśli gnają mi przez głowę, od dziewczyny, z którą chodziłem tamtego lata, przez sagę Briana Wilsona, po ostatni wywiad z Mike'em Love, znaleziony i przeczytany na Facebooku. Dwie minuty i szesnaście sekund później jestem z powrotem w teraźniejszości, skupiony na drodze, a paratekstualne echo Wendy wciąż gra w mojej głowie.

Czy możemy więc powiedzieć, że jesteśmy post-paratekstualni? Przyswoiliśmy wszystko, czego nauczył nas Genette, a mimo to zawieszamy nasz sceptycyzm i ulegamy przezroczystości wielkiej sztuki, osuwając się we wspomnienia i nostalgię. Kilka tygodni temu spontanicznie wziąłem z półki Portret damy Henry’ego Jamesa. Pochłonął mnie i nie byłem w stanie go odłożyć. Mimo lat spędzonych w cyfrowym zanurzeniu i metakrytycznego komentarza, zatraciłem się w tej książce, jakby był rok 1955. Jasne, miałem przy sobie telefon i od czasu do czasu zerkałem na powiadomienia z Twittera, ale Henry James półtora wieku później, mimo napływu teorii krytycznej i technologicznych rewolucji - których większości sam doświadczyłem - nadal mnie powala. Mimo krytycznego sceptycyzmu, wciąż omdlewam w obliczu wielkiej sztuki. Choć każdą książkę można zdekonstruować, niektóre opierają się takim zabiegom. Kiedyś próbowaliśmy z grupą studentów popsuć Czerwona taczkę Williama Carlosa Williamsa, używając internetowych silników kiereszujących teksty. Nieważne jak bardzo tekst był rozbity, nadal chodził tak, jak zaplanował to Williams. Mogliśmy go zdekonstruować, ale nie mogliśmy go zniszczyć. Niektóre dzieła po prostu są odporne. Czasem treść pozostaje treścią.

Przypomina mi to czas, gdy mieliśmy z żoną pierwsze dziecko. Mimo wielu lat praktykowania feminizmu, kiedy przyszło co do czego i się ono zjawiło, uwidoczniły się zasadnicze różnice między płciami. Wszystko to przynajmniej tymczasowo poszło $\mathrm{w}$ odstawkę i zaczęły obowiązywać bardzo tradycyjne role genderowe. Nigdy nie zapomnieliśmy o naszym feminizmie i wróciliśmy do niego później, gdy już mogliśmy złapać oddech, ale na co najmniej dwa lata zawiesiliśmy naszą podejrzliwość. Choć mogłem do upadłego negować czytelność i kontekst, koniec końców zdarzają się sytuacje, kiedy wszystko to się rozmywa. Czyż nie jest tak, że nie jesteśmy tylko albo tacy, albo inni, że stanowimy raczej mieszankę radykalnie sprzecznych impulsów? Mimo mnogości systemów dostarczania treści, technologii i interfejsów, gitara Django Reinhardta i słowa Henry’ego Jamesa nadal trafiają w dziesiątkę, rozbijając

\footnotetext{
${ }^{2}$ Okładka rzeczonej książki wykonana była z papieru ściernego [przyp. tłum.].
} 
wszystkie mury, które wokół nich wzniosłem. Genette odegrał kluczową rolę w uwidacznianiu tego, co było wcześniej niewidoczne, tak jak Cage albo Duchamp. Jednak tak jak w przypadku Cage'a czy Duchampa, możemy dostosowywać doświadczenia konsumpcji kultury, kręcąc gałką zależnie od charakteru każdego z nich. Mimo tego wszystkiego, co wiemy o Duchampie, nadal sikamy do pisuarów; mimo wszystkiego, co wiemy o Cage'u, nadal zakochujemy się w popowych piosenkach; mimo wszystkiego, co wiemy o Genetcie, nadal zatracamy się w lekturze. Skoro parateksty mojego MP3 zostały spłaszczone, czy możemy powiedzieć, że cyfrowość spłaszcza palimpsesty na rzecz kompresji? Czy pamięć jest paratekstem artefaktu? (Być może od zawsze tak było.)

Pójdźmy jeszcze o krok dalej i stwierdźmy, że technologia mobilna zmienia przestrzeń realną w paratekst. Świat wycofuje się na drugi plan; to pracujący w tle silnik, podrzędny do tego stopnia, że real staje się narzędziem w służbie tego, co cyfrowe. Na moim ekranie wyświetla się content, a cała reszta - w tym osoba siedząca przy mnie, też wgapiona w swój smartfon staje się paratekstem. Jestem znacznie bardziej zainteresowany osobą, z którą esemesuję, niż osobą siedzącą obok mnie, a która sama też mnie sparatekstualizowała na rzecz kogoś fizycznie oddalonego. Czy możemy wobec tego powiedzieć, że z powodu smartfonów przestrzeń trójwymiarowa stała się paratekstem przestrzeni dwuwymiarowej? W niespodziewanym zwycięstwie Greenbergowskiego modernizmu płaskość ekranu stała się bardziej realna i prawdziwa niż geografia. Mapa rzeczywiście stała się terytorium. Informacja wyparła fizyczność.

Szukam słowa, które mogłoby opisać w realu grę pomiędzy pierwszym planem (przedmiotem) a tłem (paratekstem), jaka zdarza się w fotografii. Istnieją obiektywy i filtry, które skupiają ostrość na przedmiocie, podczas gdy całe tło zostaje rozmyte, co jest, jak sądzę, dobrą metaforą paratekstualności poza granicami strony. Możliwość zmiany ostrości pomiędzy pierwszym planem a tłem to przesuwalna paratekstualność. Stoimy tutaj w rozkroku pomiędzy tym, co informacyjne, a tym, co fizyczne. W tej chwili siedzę w poczekalni na lotnisku i piszę ten tekst na laptopie. Jasno świecący komputer w pełni skupia moją uwagę (wzrokową, fizyczną i intelektualną). A jednak ta przestrzeń jest wypełniona elementami paratekstualnymi: grupką mężczyzn, którzy niedaleko cicho rozmawiają, otaczającymi mnie dźwiękami lotniska, architekturą tego miejsca, różnymi elementami dekoracyjnymi i oświetleniowymi, i tak dalej, aż po sieć wi-fi, do której jestem podpięty; nawet krzesło, na którym siedzę, jest paratekstem tego eseju. Żyjemy w rysunku M.C. Eschera; zamieszkujemy czterowymiarowy sześcian, który jednocześnie zwija się w sobie i rozszerza. Gra pomiędzy znaczącymi i znaczonymi ciągle trwa - niespokojnie morfują one pomiędzy tekstem i paratekstem, co odsyła nas na powrót do słabego punktu teorii Genette'a, to znaczy do założenia o istnieniu jakiejś stabilności. Przeciwnie, wraz z tym, jak parateksty stają się tekstami, a teksty przechodzą w parateksty, grunt wciąż osuwa się nam spod stóp i podobna rzecz dzieje się też ponad naszymi głowami.

przekład z języka angielskiego: Krzysztof Hoffmann i Weronika Szwebs 


\title{
SŁOWA KLUCZOWE:
}

psychoparatekstualność

\begin{abstract}
ABSTRAKT:
Artykuł opisuje doświadczenie psychoparatekstualności we współczesnym życiu codziennym. $\mathrm{Na}$ wybranych przykładach autor pokazał, w jaki sposób liczne zindywidualizowane, często przypadkowe dodatki do dzieł i tekstów występujące w używanych kopiach stają się tekstami właściwymi dla czyjegoś świata życia. Pozwala to na dalsze twierdzenie, iż we współczesnym środowisku medialnym paratekstualna stała się cała rzeczywistość wobec tekstów zjawiających się na ekranach laptopów i smartfonów.
\end{abstract}




\section{parateksty}

życie codzienne

\section{NOTA O AUTORzE:}

Kenneth Goldsmith jest autorem trzynastu książek poetyckich. Naucza sztuki pisania na Uniwersytecie Pennsylwanii. W maju 2011 r. został zaproszony przez Prezydenta Obamę do wystąpienia na Święcie Poezji Amerykańskiej zorganizowanym w Białym Domu, gdzie także przeprowadził warsztat poetycki dla Pierwszej Damy Michelle Obamy. W 2013 roku został Poetą Laureatem Muzeum Sztuki Nowoczesnej w Nowym Jorku. Jego ostatnia książka, Marnowanie czasu $w$ Internecie, zawiera refleksje o kulturze cyfrowej. 